\title{
EXPLORING RELATIONS BETWEEN RESILIENCE, TRAUMA AND DEPRESSION IN CHILDREN
}

\author{
MARIJA CRNKOVIĆ ${ }^{1}$, RENATA MILJEVIĆ-RIĐIČKI ${ }^{2}$ \\ ${ }^{1}$ Poliklinika za zaštitu djece i mladih grada Zagreba, Zagreb, Croatia, contact: marija.krmek@poliklinika-djeca.hr \\ ${ }^{2}$ Učiteljski fakultet Sveučilišta u Zagrebu, Croatia
}

Received: 14.04.2020.

Original research article

Accepted: 11.11.2020.

UDK: 159.922 .7

doi: 10.31299/hrri.56.2.3

\begin{abstract}
Defining psychological resilience is a challenge for researchers and mental health professionals. More recent understandings of resilience define it as the capacity of a dynamic system to successfully adapt to disruptive factors that threaten the sustainability or development of that system. The present study aimed to examine the relationships between psychological trauma, depression and certain factors of resilience in a clinical sample of children $(N=103)$. To test the hypotheses, the following measuring instruments were used: the Trauma Symptom Checklist (TSCC), Beck Youth Inventories - Second Edition, Child and Youth Resilience Measure (CYRM-28), as well as assessment of psychotraumatization. The results were not quite consistent with previous studies of resilience, so that the hypothesis that abused, non-traumatised children would have significantly higher scores on the resilience measure than abused children was not confirmed. The results do suggest that abuse is more likely to occur among children whose caregivers do not provide care for their physical and psychological needs. It has also been confirmed that caregivers' neglect of psychological needs is related to more significant negative psychological outcomes than caregivers 'neglect of physical needs. Additionally, the study found a greater negative correlation between resilience and depression in traumatised children than in non-traumatised children.
\end{abstract}

Keywords: depression, resilience, psychological trauma, abuse

\section{INTRODUCTION}

The psychological construct of resilience has been quite extensively covered and discussed in the literature over the last few decades (Reuther and Osofsky, 2013). There have also been different points of view about resilience and therefore different definitions. Masten (2014, p.10) defines resilience as "the capacity of a dynamic system to adapt successfully to disturbances that threaten the viability, function or development of that system". According to the same author, resilience in the context of developmental psychology implies a child (1) who relatively successfully resolves key developmental tasks that are important for the child of a certain age in a particular culture, and (2) who is experiencing or has experienced a particularly adverse situation/s (Masten et al., 1999). Research results show that the development of resilience begins from the earliest childhood, and that the acquired ways of reacting and fac- ing adverse events in childhood have a significant effect on later development and on ways of coping with stress and problems (Horning and Rouse, 2002; Masten, 2014). Ungar offers an instrument that measures resilience, the CYRM (described later in the section "Instruments"), which we have used in the present research, so we decided to use his definition of resilience (although some definitions overlap and do not exclude each other). His definition of resilience (Ungar, 2008, p. 225) includes characteristics of the context and protective factors, namely health sustaining resources: "In the context of exposure to significant adversity, whether psychological, environmental, or both, resilience is both the capacity of individuals to navigate their way to health-sustaining resources, including opportunities to experience feelings of well-being and a condition of the individual's family, community and culture to provide these health resources and experiences in culturally meaningful ways". After experiencing difficult life situations 
(such as for example abuse), traumatic reactions can occur that are visible on an emotional, physical, mental and behavioural level. However, if a person has developed resilience to such experiences, more severe reactions will be less likely, and the person will adjust positively to the new situation over time and continue further successful development. Hjemdal, Friborg, Stiles, Martinussen and Rosenvinge (2006) define resilience as the protective factors, processes, and mechanisms that contribute to a good outcome, even though if someone has lived through stressors that represent significant risk for developing psychopathology. Access to resources and opportunities affect resilience. Tempski et al. (2015) view resilience as a result of the interaction of an individual's social support, experiences, values and cultural, social, and ethical influences. Negative effects of adverse life circumstances are modified by protective factors which help to strengthen resilience (Schoon, 2006). Ungar, Ghazinour, and Richter (2013) define resilience as the ability of an individual to successfully use his or her psychological, social, cultural and physical resources in difficult life situations in order to cope with problems and adverse situations. Resilience is also the capacity of an individual to acquire and realize these resources and successfully use them in a meaningful way.

Protective factors are considered key in achieving resilience and overcoming stressful life situations (Windle, 2011). These factors interact with risk and contribute to stronger resilience and are recognized through three levels - individual (psychological or neurobiological factors), immediate social environment (family connection, parental support) and community (support systems, institutional and economic factors) (Windle, 2011). Personal sources of resilience, understood as dynamic concepts, are influenced by active family transaction processes: participating in the immediate and wider social network of family members, in resource mobilisation and in the overcoming of obstacles in complex environmental conditions (Ungar, 2010). Walsh (2016) also states that human successful and unsuccessful functioning is the result of the interaction of individuals, families, communities, and wider systems. Their interaction affects vulnerability and resilience in dealing with stressful life experiences and other difficult-to-change situations.

\section{ABUSE AND NEGLECT AS A SOURCE OF PSYCHOLOGICAL TRAUMA IN EARLY CHILDHOOD}

Any painful event or experience that causes some permanent consequences is considered to be a trauma (Petz, 2005). Traumatic events acutely disrupt the usual sense of control over a person's life, the feeling of being connected with others and the meaning that a person attaches to the world around him or her (Van der Kolk et al., 2005). Due to its intensity and quality, a traumatic event, unlike a stressful event, will cause suffering and pain to most people regardless of their physical and emotional state before the event and regardless of their coping strategies (Arambašić, 2000). This means that trauma is an emotional state that occurs as a consequence of traumatic events and reactions to traumatic events are considered to be understandable or normal reactions to abnormal circumstances. They can immediately follow the traumatic experience, but can also appear later, for example several weeks and/or months later, or even much longer afterwards (Arambašić, 2000).

Traumatic events include various forms of violence against children, which can be divided into physical, emotional and sexual abuse, as well as neglect (Buljan Flander and Ćosić, 2003). According to WHO data (2014), every fourth person in the world was physically abused in his or her childhood. Finkelhor et al. (2013) state that one in five children experiences some form of neglect before the age of seventeen. In 2006, the Polyclinic for the Child and Youth Protection of the City of Zagreb and the non-governmental organisation Brave Phone conducted a national study on the prevalence of abuse and neglect of children in Croatian secondary schools. The results show that $15.9 \%$ of children were exposed to physical abuse, $16.5 \%$ to emotional, and $13.7 \%$ to sexual abuse (Buljan Flander, 2007).

Many studies reveal that abuse and neglect are one of the most frequent causes of psychological trauma in early childhood, and that adverse factors in childhood are responsible for nearly $30 \%$ of all 
mental disorders in adulthood (Arata et al., 2005; Kessler et al., 2010). Individuals who experienced more traumatic experiences during childhood have a greater probability of developing a complex form of post-traumatic stress disorder (Van der Kolk et al., 2005).

In the case of abused children, these disruptions are obvious, involving some form of abuse, which may be physical, emotional, or sexual abuse, witnessing violence between people who are close, domestic violence or neglect. The consequences may manifest themselves as disrupted health, especially mental problems, such as depression, anxiety and addiction; problems with social, emotional, and behavioural functioning (e.g. increased aggression); and problems with academic achievement (O Afifi and MacMillan, 2011, Domhard, Munzer, Fegert and Goldbeck, 2015). Cicchetti and Valentino (2006) state that maltreated children are more likely to develop a profile of relatively enduring vulnerability factors, placing them at great risk for future maladaptation and psychopathology.

\section{DEPRESSION AS A CONSEQUENCE OF PSYCHOLOGICAL TRAUMA}

Psychological trauma is an individual's complex reaction to being exposed to events that occur unexpectedly and suddenly, and that cause intense fear and a feeling of terror and helplessness (Reyes et al., 2019). Traumatic experiences can significantly change an individual's stable perception of his or her own value, trust in others and feeling of justice and predictability in the world. All this can lead to many negative outcomes, both for the individual and for his or her functioning in the environment.

It has been proven that traumatic events in childhood cause functional damage in the brain and this damage can remain even decades after the traumatic event (Yu et al., 2019). The depressive symptoms of persons that have a history of traumatic experiences in childhood are connected with the abnormal functioning of the brain, particularly of the sensory and attention systems. Individuals who have lived through some form of psychological trauma have a four times greater chance of experiencing depressive symptoms and other mental health problems than persons who have not experienced traumatic events in childhood (Green et al., 2010; Nakai et al., 2014). Negele, Kaufhold, Kallenbach and Leuzinger-Bohleber (2015) state in their study that over $75 \%$ of patients diagnosed with depression have a medical history of trauma in early childhood. In addition, approximately $37 \%$ of patients with clinical depression mention multiple traumatic experiences in childhood.

\section{RESILIENCE AND TRAUMATISATION}

When speaking about maltreated children, Walsh, Dawson and Mattingly (2010) state that these children are resilient if they show that they are competent in different functional areas, such as behaviour, expressing and regulating emotions, social relationships (for example, with their peers) and academic achievement. However, they emphasise that successful functioning in one area does not mean success in another area, and that, unfortunately, every fifth child who has been maltreated functions poorly in all these areas. In the study conducted by Cicchetti and Rogosch (1997), maltreated children demonstrated greater dysfunction than non-maltreated ones on several indicators of resilient functioning; some of these indicators were competence with peers, behavioural problems, school functioning and relationships with adult caregivers. Also, they stated that many of these deficits persisted across 2 or 3 consecutive years of assessment and that maltreated children exhibited a lower level of resilient functioning than did the non-maltreated children across each of the 3 years.

On the other hand, some abused children suffer no consequences in any area. We can find different data depending on the study: $10 \%$ to $53 \%$ of children who suffered sexual abuse continue to function normally (Domhard et al., 2015). We were therefore interested in investigating the protective factors that increase resilience, especially in abused children.

A survey studying resilience of sexually abused girls (interviewed during childhood, and again as adults) showed that the following had an effect on increasing resilience: a stable family environment, a less violent experience of sexual abuse, the non-repetition of sexual abuse in adulthood, 
completion of secondary school, and lack of trouble with the law in youth (Hyman and Williams, 2001). Domhard et al. (2015) in their analysis of the study of resilience also mention protective factors within the family, which were effective in spite of the experience of sexual abuse. They mention support in the family as the most important factor, but they also indicate the importance of support by the broader social community, as well as the following factors: education, affection, social and emotional competence, active confrontation with problems, internal locus of control, optimism, and attributing blame to external causes (Domhard et al., 2015).

In his multilevel perspective on resilience under conditions of extreme stress, Ciccetti (2010, p 153) says that "the advances in genomics, epigenetics, brain imaging and hormonal and immunological assay techniques will make important contribution to propelling increased knowledge about the developmental processes leading to resilience". Earlier studies have continuously provided data on the significant relation between emotional abuse or neglect and psychopathology (McCrory, De Brito and Viding, 2012), which primarily consists of depression in adults, which in the mentioned cases appears earlier, lasts longer and manifests itself in multiple episodes during their lifetime (Klein, Shankman, Lewinsohn, and Seeley, 2009).

Resilience represents an important factor in understanding the relationship between trauma and depression (Luthar, Cicchetti and Becker, 2000). Less resilient individuals will have a higher probability of developing depressive or anxious symptomatology after living through trauma than those who are more resilient (Hoge, Austin and Pollack, 2007).

The aim of the present study was to explore relations between resilience, trauma and depression in a clinical sample consisted of patients in a public health institution (specialised for traumatised children). We were interested to find out whether higher resilience in children and adolescents is associated with less adverse emotional consequences (not traumatised and not depressive) in the presence of inappropriate environmental factors (abuse). Also, we examined the relation between abuse and the caregivers' fulfilment of needs, which earlier stud- ies showed to be one of the factors that contribute to higher resilience in children, and the relation between (lack of) fulfilment of needs and psychological disorders. Lastly, we tested the moderating effect of traumatisation on the relation between resilience and depression.

\section{METHOD}

\section{Participants}

In 2019, a total of 103 children who were patients of the Polyclinic for the Child and Youth Protection of the City of Zagreb took part in the study. These 103 children were selected because they were tested with the same tests during clinical assessment, so that they could be compared. Therefore, it was a clinical sample consisting of 49 boys and 54 girls. The average age was 12.38 years, with a standard deviation of 2.458. Out of 103 surveyed children, 72 had not been traumatised, while 31 had been. Also, in the whole sample, 34 children had been abused and neglected. Among them 12 had been emotionally abused ( 2 by mother, 6 by father, 4 by mother and father), 4 sexually ( 1 by father, 2 by family friend or neighbour, 1 by stepfather), and 8 physically ( 3 by mother, 5 by father). Ten had witnessed family violence, in which the perpetrator had been the father in 5 cases, the stepfather/stepmother in 2 cases, or both mother and father in 3 cases. A total of 16 had been neglected, 5 by the mother, 7 by the father, and 4 by both mother and father. Four had been bullied by peers. Some of the participants had experienced multiple kinds of abuse, so the total numbers above may exceed the total of 34 abused and neglected children. The others had come to the Polyclinic for various reasons: parental divorce $(\mathrm{N}=30)$, other traumatic event $(\mathrm{N}=9)$, grieving $(\mathrm{N}=5)$, learning disabilities $(\mathrm{N}=14)$, or behavioural difficulties $(\mathrm{N}=11)$. More on how participants were divided into traumatised and non-traumatised groups can be found below under Instruments - Psychotraumatisation.

\section{Instruments}

Instruments were selected according to the convenience of the clinical sample: they were initially administered by the psychologists for the purpose of their clinical assessment, but psychologists were 
asked to include the CYRM. Although TSCC and BYI-II seem similar, the TSCC is more focused on trauma symptoms and BYI-II gives us more valuable data about depression. Because of the specifics of the sample (traumatised, abused children), we wished to use all these data to ensure more precise and useful results.

The Trauma Symptom Checklist for Children - TSCC (Briere, 2011) is a self-report measure of post-traumatic stress and related symptomatology. The TSCC scale is used for assessing children who have experienced certain traumatic events (physical and sexual abuse, peer violence, major loss, witnessing violence among others and natural disasters). The scale consists of 54 items that include two validity scales and six clinical scales (anxiety, depression, anger, posttraumatic stress, dissociation and sexual concerns). The Croatian standardisation of the Trauma Symptom Checklist for Children was conducted on a normative sample of elementary and secondary-school students (N $=295$ ), on children tested at the Polyclinic for the Child and Youth Protection of the City of Zagreb in whom the indicator of exposure to abuse or to a traumatic event was not found $(\mathrm{N}=148)$, and on a clinical sample $(\mathrm{N}=794)$ of children tested at the Polyclinic for the Child and Youth Protection of the City of Zagreb, who had been exposed to some form of traumatic experience (Briere, 2011). This standardisation showed that the range of Cronbach's alpha for clinical TSCC subscales in the normative sample was from .66 to .80 , and in the clinical sample from .66 to .84 (Briere, 2011).

The Beck Youth Inventory - Second Edition (BYI-II) (Beck, Beck, Jolly and Steer, 2011) includes five different inventories - depression, anxiety, anger, disruptive behaviour and self-concept. Each inventory contains 20 statements, and the children's task is to assess how often a particular statement is true for them on a scale of 0 (never), 1 (sometimes), 2 (often) or 3 (always). The Croatian standardisation of the BYI-II (Beck et al., 2011) inventory was conducted on 835 elementary and secondary-school students (412 males and 423 females) from the age of 7 to the age of 18 from all parts of the Republic of Croatia. This standardization showed that the range of Cronbach's alpha for BYI-II subscales was from .83 to .93 (Beck et al., 2011).

The Child and Youth Resilience Measure (CYRM-28) (Ungar and Liebenberg, 2011) contains 28 items measuring psychological resilience. All items are rated on a 5-point scale from 1 (does not describe me at all) to 5 (describes me well), with higher scores indicating increased resilience processes. The resilience assessment scale for children and adolescents provides high reliability when measuring resilience dimensions, and includes three subscales: personal, relational, and contextual factors. This measure is presently the only intercultural instrument to study resilience. The three-factor structure of the scale has been confirmed by the instrument's author, as well as by other researchers (Lee et al., 2010; Martin et al., 2015, Liebenberg et al., 2016), and explains $44 \%$ of the total variance. The scale contains eight subscales: personal skills, peer support, and social skills, which fall under the personal factor; physical caregiving and emotional caregiving, which fall under the relational factor; and spiritual experiences, education and culture, which fall under the contextual factor. The CYRM28 has been translated into Croatian and used in other studies, and therefore validation has been effected. It has shown good psychometric properties so far in Croatian samples, with Cronbach's alpha of .88 for the global scale, .75 for the individual scale, .79 for the caregiver scale, and .76 for the contextual scale (Miljević-Riđički, Simoes and Kimber, 2020). The instrument is available and can be freely applied based on the author's manual.

Psychotraumatisation. Decisions about whether participants had experienced psychotraumatisation were made on the basis of an assessment by a multidisciplinary team (psychiatrist, paediatrician, psychologist, social worker, and social pedagogue), as part of a team process at the Polyclinic for the Child and Youth Protection of the City of Zagreb, which is specialised for working with traumatised children. The participants were put into "yes" or "no" categories according to the psychotraumatisation criterion, made on the basis of the professional knowledge of every team member, who was an expert specially educated in the field of traumatisation and child abuse, and on the basis of the diagnoses that the multidisciplinary team made in their 
joint test analysis. This was the approach applied for traumatisation, but not for assessment of core test results, for example, because we considered assessment by a team of special experts to be more reliable and trustworthy, especially given that abuse and neglect are sensitive topics (a child's narrative is often the only evidence of abuse), and given the size of our sample and the fact that children may give socially appropriate answers (especially in smaller samples) due to the pressures connected to the assessment (e.g. pressure about the abuser going to jail, parental manipulation during divorce, the child's desire to avoid other experts). With a view to using simpler language, we differentiate in this text between participants who were abused, which means those who experienced abuse/neglect, on the basis of the most objective information available; and participants who were traumatised, i.e. who experienced emotional reactions as a consequence of traumatic events. Therefore, some participants were both abused and traumatised $(\mathrm{N}=18)$ : in other words, they experienced maltreatment and exhibited emotional signs of trauma. Other participants were abused but not traumatised $(\mathrm{N}=16)$ : they experienced maltreatment, but did not exhibit emotional traumatic reactions.

\section{Procedure}

This survey was conducted at the Polyclinic for the Child and Youth Protection of the City of Zagreb. The participants were children (patients) included in the analysis of the Polyclinic's multidisciplinary team. The testing was conducted as part of regular psychological procedures, except that psychologists were asked to add the CYRM to their usual testing materials. All the data for this study were extracted from the medical charts and reports of the multidisciplinary team, and from the Polyclinic's database containing patient information. For the purpose of this study, all the data were anonymised, number-coded, and stored in the medical files within the institution, in conformity with the rules of the health institution, and with all the ethical and professional principles related to confidentiality. Since the study was conducted after the patients were in the Polyclinic and it was based on using previously collected clinical data, approval to use the data was obtained from the
Polyclinic's ethics board and the director of the institution. All instruments were administered at the same time for each participant.

\section{RESULTS}

Table 1 contains the descriptive-statistical parameters of some of the scales used in this study.

Descriptive - statistical parameters were calculated for the whole sample of participants. It can be seen that among TSCC subscales, the highest result was on PTSP and the lowest was on anger without a high tendency toward under- or hyper-response. BYI-II subscales showed that our participants had good self-concept $(M=39.43$, $\max =58)$, with the highest results on the anxiety subscale and the lowest on disruptive behaviour. On CYRM subscales, the highest result was on physical caregiving, and the lowest was on spiritual experiences.

\section{The relation between resilience and trauma- tisation}

A range of t-tests were conducted to test the differences in resilience between traumatised and non-traumatised abused children. All the t-tests were conducted only on the subsample of persons who had been abused $(\mathrm{N}=34)$. Traumatisation was used as an independent variable, while the dependent variables were the subscales of the resilience questionnaire, that is, the total result of the questionnaire for this subsample. It was assumed that the participants in the group of abused, non-traumatised $(\mathrm{N}=16)$ respondents would show higher score for resilience than those who were abused and traumatised $(\mathrm{N}=18)$. However, the t-tests showed that this assumption was not valid, either for the total result $[t(34)=1.6, p=.12]$ or for most of the resilience subscales: personal factor, $t(34)$ $=1.78 ; p=.09$; relational factor, $t(34)=1, p=$ .33 ; contextual factor, $t(34)=1.29, p=.21$; peer support, $t(34)=1.2, p=.24$; social skills, $t(34)=$ $0.84, p=.41$; physical caregiving, $t(34)=-0.54$, $p=.59 ;$ psychological caregiving, $t(34)=1.41, p$ $=.17$; spiritual experiences, $t(34)=0.61, p=.55$; education, $t(34)=1.46, p=.15$; and culture, $t(34)$ $=0.85, p=.4$. A statistically significant difference appeared for only the subscale of personal skills $[t(34)=2.08 ; p=.046]$, but even in this case, the difference was very close to being statistically 
Table 1. Descriptive statistical indicators

\begin{tabular}{|c|c|c|c|c|c|c|}
\hline Scale & Min. & Max. & M & SD & Asymmetry & Flattening \\
\hline TSCC - anxiety & 0 & 20 & 5.68 & 4.745 & 0.75 & -0.1 \\
\hline TSCC - depression & 0 & 21 & 5 & 4.73 & 1.23 & 1.23 \\
\hline TSCC - anger & 0 & 17 & 3.4 & 3.79 & 1.45 & 1.81 \\
\hline TSCC - PTSP & 0 & 24 & 7.93 & 5.879 & 0.68 & -0.23 \\
\hline TSCC - dissociation & 0 & 26 & 6.32 & 5.148 & 1.08 & 1.22 \\
\hline TSCC - sexual concerns & 0 & 9 & 3.82 & 3.812 & 0.35 & -1.77 \\
\hline TSCC - underresponse & 0 & 10 & 4.44 & 3.195 & 0.18 & -1.14 \\
\hline TSCC - hyperresponse & 0 & 6 & 0.26 & 0.77 & 4.95 & 31.63 \\
\hline BYI-II - self-concept & 11 & 58 & 39.43 & 9.77 & -0.24 & -0.41 \\
\hline BYI-II - anxiety & 2 & 52 & 18.63 & 11.189 & 0.75 & -0.16 \\
\hline BYI-II - depression & 0 & 49 & 12.17 & 9.962 & 1.31 & 1.88 \\
\hline BYI-II - anger & 0 & 42 & 13.46 & 9.614 & 0.8 & 0.09 \\
\hline BYI-II - disruptive behaviour & 0 & 23 & 4.87 & 4.758 & 1.35 & 1.96 \\
\hline CYRM (all) & 2.79 & 6.50 & 4.3 & 0.526 & -0.08 & 2.62 \\
\hline CYRM (personal factor) & 2.73 & 9.27 & 4.38 & 0.71 & 2.89 & 21.46 \\
\hline CYRM (relational factor) & 1.5 & 5 & 4.46 & 0.66 & -2.32 & 6.75 \\
\hline CYRM (contextual factor) & 2.3 & 5 & 4.1 & 0.552 & -0.71 & 0.49 \\
\hline CYRM (personal skills) & 2.2 & 5 & 4.3 & 1.166 & 6.31 & 55.73 \\
\hline CYRM (peer support) & 1 & 5 & 4.24 & 0.965 & -1.45 & 1.7 \\
\hline CYRM (social skills) & 2.5 & 5 & 4.53 & 0.554 & -1.35 & 1.6 \\
\hline CYRM (physical caregiving) & 2 & 5 & 4.67 & 0.568 & -2.45 & 6.8 \\
\hline CYRM (emotional caregiving) & 1.2 & 5 & 4.38 & 0.775 & -2.03 & 4.48 \\
\hline CYRM (spiritual experiences) & 2 & 5 & 3.81 & 0.857 & -0.43 & -0.63 \\
\hline CYRM (education) & 1 & 5 & 4.33 & 0.907 & -1.6 & 2.07 \\
\hline CYRM (culture) & 2.4 & 5 & 4.2 & 0.571 & -0.79 & 0.44 \\
\hline
\end{tabular}

Legend: M - arithmetic mean, SD - standard deviation, TSCC - Trauma Symptom Checklist for Children, CYRM - Child and Youth Resilience Measure

insignificant. Abused persons who were not traumatised scored an average on the personal skills subscale of 4.3, while abused persons who were traumatised achieve 3.87 on the same subscale. The effect size was medium $(d=.69)$.

\section{The relation between abuse and the caregivers' fulfilment of needs}

Two t-tests were conducted to check the differences in caregivers' fulfilment of children's needs between abused and not abused children. These t-tests were applied on the entire sample $(\mathrm{N}=103)$; data for two participants were incomplete so they were not included ( $\mathrm{N}=101)$. Abuse was used as an independent variable, while the resilience subscales measuring the caregivers' fulfilment of physical needs and the caregivers' fulfilment of psychological needs were used as dependent variables. The results showed that there was a statistically sig- nificant difference between those abused $(\mathrm{N}=34)$ and those who are not abused $(\mathrm{N}=67)$ with respect to fulfilment of physical needs $[t(101)=2.15, p=$ $.03]$ and fulfilment of psychological needs [ $t(101)$ $=2.42, p=.02]$. Non-abused persons scored an average of 4.76 on the subscale of the caregivers' fulfilment of physical needs, while abused persons scored 4.51. The effect size was small $(d=0.41)$. Non-abused persons scored an average of 4.51 on the subscale of the caregivers' fulfilment of psychological needs, and abused persons scored 4.13. The effect size was small $(d=0.46)$.

\section{The relation between the caregiver's fulfilment of needs and psychological disorders}

In order to check the relation between the caregivers' fulfilment of physical and psychological needs on the one hand, and psychological disorders 
on the other, the correlations of these two subscales with Beck's inventories and TSCC were calculated. These correlations are shown in Table 2.

Table 2. Correlations of the caregivers' fulfilment of physical and psychological needs with the results of Beck's inventories and TSCC

\begin{tabular}{|l|l|c|c|}
\hline \multirow{5}{*}{ Beck } & Anxiety & $\begin{array}{c}\text { Physical } \\
\text { needs }\end{array}$ & $\begin{array}{c}\text { Psychological } \\
\text { needs }\end{array}$ \\
\cline { 2 - 4 } & Depression & -.08 & $-.27^{* *}$ \\
\cline { 2 - 4 } & Anger & -.12 & $-.44^{* *}$ \\
\cline { 2 - 4 } & $\begin{array}{l}\text { Disruptive } \\
\text { behaviour }\end{array}$ & $-.24^{*}$ & $-.36^{* *}$ \\
\hline \multirow{5}{*}{ TSCC } & Anxiety & $-.34^{*}$ & $-.38^{* *}$ \\
\cline { 2 - 4 } & Depression & -.06 & $-.22^{*}$ \\
\cline { 2 - 4 } & Anger & -.08 & $-.36^{* *}$ \\
\cline { 2 - 4 } & $\begin{array}{l}\text { Posttraumatic } \\
\text { symptoms }\end{array}$ & $-.24^{*}$ & $-.34^{* *}$ \\
\cline { 2 - 4 } & Dissociation & -.14 & $-.31^{* *}$ \\
\cline { 2 - 4 } & Sexual concerns & -.17 & $-.34^{* *}$ \\
\hline
\end{tabular}

Legend: $*-p<.05, * *-p<.01$.

Table 2 shows that almost all subscales of Beck's inventories and the TSCC were significantly correlated with psychological needs; only Sexual concerns was not. Physical needs were significantly correlated with Anger and Disruptive behaviour.

\section{Testing the moderating effect of traumatisation on the relation between resilience and the results of depression}

In order to discover whether the relation between the total results on the CYRM and the total result on the TSCC depression scale (as a most severe symptom due to suicidal risk) depends on traumatisation, a regression analysis was conducted to check the interactive effect. Traumatisation and the centralised value of the CYRM results were introduced as a first step, while their mathematical product was introduced as a second step. When using the total result on the TSCC depression scale as a criterion, the moderating effect was significant: $\mathrm{F}(1,98)=4.65 ; p=.03, \Delta R^{2}=.03$. The results of this regression analysis are summarised in Table 3. Figure 1 shows that in traumatised children there was a greater negative connection between resilience and depression than in children who were not traumatised. In other words, children who achieved a lower score on the resilience scale, achieved a higher score on the depression scale.

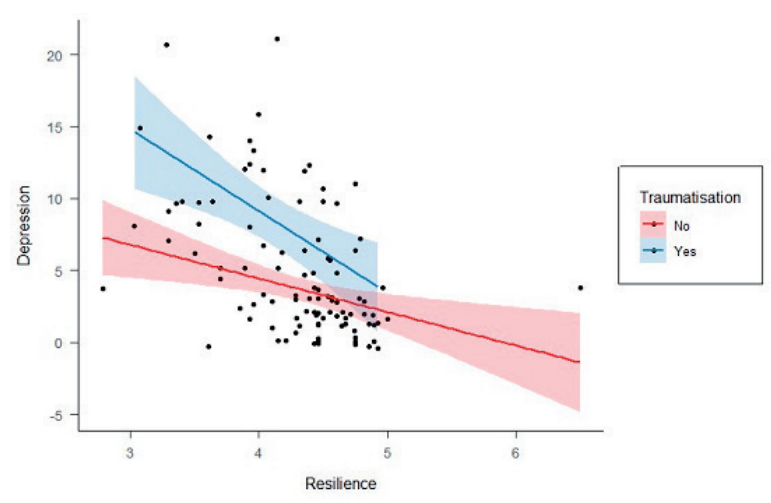

Figure 1. Graph of the moderating effect of traumatisation on the link between CYRM and TSCC-depression

\section{DISCUSSION}

Numerous biopsychosocial and cultural factors affect the reactions of individuals after traumatic experience (Norman et al., 2012). Several studies show that there are situations where children, after

Table 3. Results of the test of the moderating effect of traumatisation on the relation between CYRM and TSCCdepression

\begin{tabular}{|c|c|c|c|c|c|c|c|c|c|c|}
\hline Step & Predictor & B & $\beta$ & SDB & $\mathbf{t}$ & pt & $\mathbf{F}$ & df & pF & $\mathbf{R 2}$ \\
\hline \multirow[t]{3}{*}{1.} & Traumatisation & 3.99 & .39 & 0.853 & 4.68 & $<.001 * *$ & \multirow[t]{2}{*}{27.35} & \multirow[t]{2}{*}{2,99} & \multirow[t]{2}{*}{$<.001 * *$} & \multirow[t]{2}{*}{.36} \\
\hline & CYRM & -3.41 & -.38 & 0.738 & -4.62 & $<.001 * *$ & & & & \\
\hline & Traumatisation & 3.67 & .36 & 0.85 & 4.31 & $<.001 * *$ & & & & \\
\hline \multirow[t]{2}{*}{2.} & CYRM & -2.33 & -.26 & 0.88 & -2.65 & $.009 * *$ & 20.45 & 3,98 & $<.001 * *$ & .39 \\
\hline & CYRM $\mathrm{x}$ traumatisation & -3.35 & -.22 & 1.553 & -2.15 & $.03 *$ & & & & \\
\hline
\end{tabular}

Legend: $\mathrm{B}$ - non-standardised regression coefficient, $\beta$ - standardised regression coefficient, $\mathrm{SDB}-$ standard error B, $\mathrm{t}-\mathrm{value}$ of the $\mathrm{t}$-test for testing the significance of individual predictors, $\mathrm{pt}$ - $\mathrm{p}$-value $\mathrm{t}, \mathrm{F}$ - value of the F-test for testing the significance of the entire model, $\mathrm{df}$ - degrees of freedom, $\mathrm{pF}$ - p-values $\mathrm{F}, \mathrm{R} 2$ - coefficient of determination, $*-\mathrm{p}<.05, * *-\mathrm{p}<.01$. 
experiencing trauma, do not experience negative outcomes in the form of health problems (Holmes et al., 2015). Some authors claim that the reason for this lies precisely in psychological resilience, that is, the capacity to adapt to adverse environmental factors (Basim and Cetin, 2011). However, children who experience a traumatic event in the form of abuse or neglect are at a significantly increased risk of manifesting atypicalities in neurobiological processes, physiological responsiveness, developing emotional problems and problems in attachment relationships, behavioural problems, problems in information processing, school functioning as well as adaptation problems, problems with peers and in romantic relationships (Cicchetti, 2010; Norman et al., 2012).

The results of the implemented study show that the physical and psychological needs of nonabused children are satisfied by caregivers to a greater extent than the needs of abused children. These situations can represent a risk of some form of neglect, precisely because parents or caregivers do not succeed in fulfilling the child's basic physical, developmental or emotional needs (Cohen, Menon, Shorey, Le and Temple, 2017). This can also be a risk factor for future recovery because it is known that the best predictor for healing after traumatic events is parental support, i.e. parental ability to recognise and satisfy child's needs (van de Kamp, 2005). Neglect represents a risk factor for the development of numerous internalised problems (Norman et al., 2012), depression and anxiety (Hildyard and Wolfe, 2002), both in adolescence and in adulthood.

As said before, parental support is a significant mediator in determining the extent to which children recover after victimisation (van der Kamp, 2005). Family support and appropriate parental emotional functioning mitigate the potential development of posttraumatic symptomatology (Briere et al., 2017). The relationship with caregivers or parents has proven to be a key protective factor against the development of psychological disorders after experiencing trauma. The meta-analysis results of Trickey et al. (2012) show that a supportive relationship of the caregiver towards the child results in the less frequent development of psychopathology after experiencing trauma, which is consistent with the results of our research. On the other hand, situations where the parents are the source of trauma, or the perpetrators of abuse, have a significantly negative effect on the recovery of children after experiencing the trauma (van der Kolk, 2005). In other words, when the relationship between the child and the caregiver is the source of the trauma, many critical developmental competences may be threatened, and the results of studies have revealed the development of patterns of insecure attachment in over $90 \%$ of cases of child abuse and neglect by parents or caregivers (van der Kolk, 2005; Sousa et al., 2011).

Schulz and Sherwood (2008) claim that the harmful effects of failing to fulfil the psychological needs of children have proven to be more intense than not meeting their physical needs. Studies are also consistent in finding greater effects of psychological neglect than of physical neglect on the development of internalised problems in children (Van Vugt et al., 2014; Cohen et al., 2017). The results of this study confirm that a lack of care by the caregiver towards children's psychological needs is related to more significant negative psychological outcomes than a lack of care toward their physical needs. The moderate connection between the caregiver's non-fulfilment of a child's physical needs and the lack of fulfilment of his or her psychological needs, obtained by earlier studies, suggests that physical and emotional neglect often happen simultaneously, and that they belong to different categories of (non-)fulfilment of the basic needs of children (Dubowitz, Pitts and Black, 2004; Cozza et al., 2015). The results of the study conducted by Clemens et al. (2018) show a significant connection of nearly all types of abuse and neglect during childhood with various forms of health issues in adulthood. It has been shown that psychological neglect, in contrast to physical neglect, is connected with all forms of health issues.

Considering the high prevalence of psychological and emotional neglect, which, in some analyses, was nearly two to three times higher than the prevalence of abuse (Schilling et al., 2016; Witt et al., 2017), the results of the present study indicate potential risk factors for the development of a number of mental health issues, which could occur due 
to the failure by caregivers to meet psychological needs during childhood.

The hypothesis that abused non-traumatised children would score significantly higher on the resilience questionnaire than those who are abused and traumatised was not confirmed in this study. The obtained results are not fully consistent with previous findings in the field of psychological resilience (Hyman and Williams, 2001; Beutel et al., 2017). However, these findings potentially support the thesis that the prediction of resilience is complex precisely due to the lack of generally defined constructs that constitute resilient behaviour (Agaibi and Wilson, 2005). As stated above, in the last several decades, some empirical studies have defined resilience as the absence of psychopathology, others as inappropriate confrontation patterns, and still others as prolonged stress-reaction patterns (Reuther and Osofsky, 2013). In addition, when interpreting the present results, we should keep in mind that resilience may also be genetically conditioned (Feder, Nestler and Charney, 2009), which could additionally explain the present results that there was no difference in resilience between abused children who were traumatised or not. The hypothesis of the genetic conditioning of resilience, or of its relative stability through life, is confirmed by a study on a sample of low-resilience individuals who experienced abuse and neglect in childhood, of whom only $22 \%$ showed resilience as adults on the basis of a comprehensive evaluation of healthy functioning (McGloin and Widom, 2001).

Research and clinical practice agree that exposure to traumatic events has a significantly negative effect on brain development in early childhood (Carrion, Weems and Bradley, 2010). Preschool children with a history of complex trauma are at greater risk of not developing adequate mental capacities necessary for modulating emotions in stressful situations (Cook et al. 2017), the sympathetic adrenomedullary system (SAM), and the hypothalamic-pituitary-adrenal axis (HPA) (Syed, Cranshaw and Nemeroff, 2020). De Bellis and Thomas (2003) emphasise that abnormally high corticosteroid secretion induced by corticotrophin is predicted better by child abuse and neglect than by other syndromes, depression or suicide attempts.
Considering the above, as well as many other findings that support the complexity of the brain neurobiology of abused and neglected children, it can be hypothesised that abuse and neglect are a specific and complex form of trauma whose relationship with resilience can hardly be explained by the present empirical achievements of studies conducted so far.

Authors such as Bonanno, Galea, Bucciarelli and Vlahov (2006) state that increased resilience after experiencing psychological trauma can be related to the involvement of individuals in programmes of mental health institutions, or with social support and psychological growth, which can result in findings that indicate that persons who were traumatised after being abused achieve high scores in resilience measures. In the context of factors connected with trauma, the literature often mentions the concept of posttraumatic growth (a mechanism of facing a traumatic event by focusing on the positive effects of stressful events), which implies changes related to more relationships with others, awareness of new opportunities, personal strength, spiritual change, and greater appreciation of life (Tedeschi and Calhoun, 2004).

Therefore, trauma in childhood is connected with an increased risk of developing multiple forms of psychological problems, one of the most frequent being depression (McLaughlin et al., 2012; Spilman, Smith, Schirmer and Tonui, 2015; McLaughlin and Lambert, 2017). The results of this study support the findings of studies that establish a greater negative relation of resilience and depression in traumatised individuals than in non-traumatised ones (Campbell-Sills, Cohan and Stein, 2006; Simeon et al., 2007; Diehl and Hay, 2013; Norton, 2017).

It is also necessary to stress that the participants of earlier studies (Holmes et al., 2015; Poole, Dobson and Pusch, 2017) were mainly adults with early childhood trauma, and that the participants of the study at hand were children who had recently experienced a traumatic event. For the sake of further comparison, it is necessary to invest additional effort in analysing the relationship between resilience and depression on a sample of traumatised children and adolescents, as well as between resilience and trauma in general (Alvord and Grados, 
2005; Loh, Schutte and Thorsteinsson, 2014). Increased knowledge of protective factors and a further study of the relationship between resilience and depression in children and adults who experienced trauma may help plan and apply therapeutic interventions and improve the general welfare of children (O Afifi and MacMillan, 2011, Howell and Miller-Graff, 2014). When implementing clinical interventions, the developmental characteristics of the victim, and the possibility of seeking social support from significant others need to be considered (Domhard et al., 2015). Family-level factors of stable family environment and supportive relationships appeared to be consistently linked with resilience (O Afifi and MacMillan, 2011). This study tells us that in treatment it is important to work with parents of abused children, to teach them how to better satisfy children's psychological needs, and that this may be even more important than just satisfying physical needs.

\section{INSTEAD OF A CONCLUSION: POTENTIAL ADVANTAGES AND DISADVANTAGES, AND GUIDELINES FOR FUTURE RESEARCH}

In the context of the studied area, there is still a lack of research on a clinical sample of children and youth. It is therefore necessary to invest additional effort in research to clarify the relationship between psychological trauma, resilience and adverse consequences for mental health (Loh et al., 2014). In addition, the results potentially show the complexity of the traumatic experiences of abuse in childhood and the hypothesis that child abuse and neglect are neurobiologically more significant and stronger experience than certain resilience mechanisms. It would be useful to analyse these aspects in future studies. This study was implemented on a valuable clinical sample of children (abused ones). The results support the thesis that the caregivers' fulfilment of psychological needs (often underestimated) is more significant for the mental health of children and young people than the meeting of physical needs. The obtained results provide further insight into the significant relationship between the lack of fulfilment by caregivers of psychological and physical needs on the one hand, and abuse on the other. An important limitation of this study is the inability to assess causal factors due to its cross-sectional design. The potential limitations of the study relate to the relatively small number of participants and the lack of a non-clinical control group which would enable further comparisons, and potentially provide valuable insights related to resilience. 


\section{LITERATURE}

Agaibi, C. E. \& Wilson, J. P. (2005). Trauma, PTSD, and resilience: A review of the literature. Trauma, Violence and Abuse, 6(3), 195-216. DOI: 10.1177/1524838005277438

Alvord, M. K. \& Grados, J. J. (2005). Enhancing resilience in children: A proactive approach. Professional psychology: research and practice, 36(3), 238-245. DOI: 10.1037/0735-7028.36.3.238.

Arambašić, L. (2000.). Stresni i traumatski događaji i njihove posljedice, u: L. Arambašić (ur.), Psihološke krizne intervencije, Društvo za psihološku pomoć, Zagreb, 11.-31.

Basim, H. N. \& Cetin, F. (2011). The reliability and validity of the Resilience Scale for Adults-Turkish Version. Turk Psikiyatri Derg, 22(2), 104-114.

Beck, J.S., Beck, A.T., Jolly, J.B. \& Steer, R.A. (2011) Beckovi inventari za mlade - drugo izdanje za djecu i adolescente - BYI-II. Jastrebarsko: Naklada Slap.

Beutel, M. E., Tibubos, A. N., Klein, E. M., Schmutzer, G., Reiner, I., Kocalevent, R. D. \& Brähler, E. (2017). Childhood adversities and distress - the role of resilience in a representative sample. PLoS One, 12(3). DOI: 10.1371/journal.pone.0173826

Bonanno, G. A., Galea, S., Bucciarelli, A. \& Vlahov, D. (2006). Psychological resilience after disaster. Psychological Science, 17 (3), 181-186. DOI: 10.1111/j.1467-9280.2006.01682.x

Briere, J. (2011). Ljestvica simptoma traume kod djece. Priručnik. Jastrebarsko: Naklada Slap

Briere, J., Runtz, M., Eadie, E., Bigras, N. \& Godbout, N. (2017). Disengaged parenting: Structural equation modeling with child abuse, insecure attachment, and adult symptomatology. Child Abuse \& Neglect, 67, 260-270. DOI: 10.1016/j.chiabu.2017.02.036

Buljan Flander, G. (2007). Izloženost djece nasilju: Jesmo li nešto naučili? U: V. Kolesarić (ur.) Psihologija i nasilje u suvremenom društvu. Zbornik radova znanstveno - stručnog skupa Psihologija nasilja i zlostavljanja, Osijek, 45-52.

Buljan Flander, G. \& Ćosić, I. (2003). Prepoznavanje i simptomatologija zlostavljanja i zanemarivanja djece. Medix, 9 (51), 122-124. Preuzeto s https://hrcak.srce.hr/20094

Campbell-Sills, L., Cohan, S. L. \& Stein, M. B. (2006). Relationship of resilience to personality, coping, and psychiatric symptoms in young adults. Behaviour research and therapy, 44(4), 585-599. DOI: 10.1016/j.brat.2005.05.001

Carrion, V. G., Weems, C. F. \& Bradley, T. (2010). Natural disasters and the neurodevelopmental response to trauma in childhood: A brief overview and call to action. Future Neurology, 5(5), 667-674. DOI: 10.2217/fnl.10.42

Cicchetti D. (2010). Resilience under conditions of extreme stress: a multilevel perspective. World psychiatry: official journal of the World Psychiatric Association (WPA), 9(3), 145-154. DOI: 10.1002/j.2051-5545.2010.tb00297.x

Cicchetti, D. \& Rogosch, F. (1997). The role of self - organization in the promotion of resilience in maltreated children. Development and psychopathology. 9. 797-815. DOI: 10.1017/S0954579497001442.

Cicchetti, D., \& Valentino, K. (2006). An ecological - transactional perspective on child maltreatment: Failure of the average expectable environment and its influence on child development. In Cicchetti, D. \& Cohen, D. J. (Eds.). Developmental psychopathology: Risk, disorder and adaptation (p. 129-201). John Wiley \& Sons Inc.

Clemens, V., Huber-Lang, M., Plener, P. L., Brähler, E., Brown, R. C. \& Fegert, J. M. (2018). Association of child maltreatment subtypes and long-term physical health in a German representative sample. European journal of psychotraumatology, 9(1). DOI: 10.1080/20008198.2018.1510278

Cohen, J. R., Menon, S. V., Shorey, R. C., Le, V. D. \& Temple, J. R. (2017). The distal consequences of physical and emotional neglect in emerging adults: A person-centered, multi-wave, longitudinal study. Child abuse and neglect, 63, 151-161. DOI: 10.1016/j.chiabu.2016.11.030

Cook, A., Spinazzola, J., Ford, J., Lanktree, C., Blaustein, M., Cloitre, M.,... \& Mallah, K. (2017). Complex trauma in children and adolescents. Psychiatric annals, 35(5), 390-398. 
Cozza, S. J., Ortiz, C. D., Fullerton, C. S., McCarroll, J. E., Holmes, A. K., Harris, A. M.,... \& Ursano, R. J. (2015). Types, subtypes, and severity of substantiated child Neglect in US Army communities. Military medicine, 180(11), 1147-1153. DOI: 10.7205/MILMED-D-14-00373

De Bellis, M. D. \& Thomas, L. A. (2003). Biologic findings of post-traumatic stress disorder and child maltreatment. Current psychiatry reports, 5(2), 108-117. DOI: 10.1007/s11920-003-0027-z

Diehl, M. \& Hay, E. L. (2013). Personality - related risk and resilience factors in coping with daily stress among adult cancer patients. Research in human development, 10(1), 47-69. DOI: 10.1080/15427609.2013.760259

Domhard, M., Munzer, A., Fegert, J.M. \& Goldbeck, L. (2015). Resilience in Survivors of Child Sexual Abuse: A Systematic Review of the Literature. Trauma, Violence \& Abuse, 16 (4) 476-493. DOI: 10.1177/1524838014557288

Dubowitz, H., Pitts, S. C. \& Black, M. M. (2004). Measurement of three major subtypes of child neglect. Child maltreatment, 9(4), 344-356. DOI: 10.1177/1077559504269191

Feder, A., Nestler, E. J. \& Charney, D. S. (2009). Psychobiology and molecular genetics of resilience. Nature Reviews Neuroscience, 10(6), 446-457. DOI: 10.1038/nrn2649

Green, J. G., McLaughlin, K. A., Berglund, P. A., Grube, M. J., Sampson, N. A., Zaslavsky, A. M. \& Kessler, R. C. (2010). Childhood adversities and adult psychiatric disorders in the national comorbidity survey replication I: Associations with first onset of DSM-IV disorders. Archives of General Psychiatry, 67(2), 113-123.

Hildyard, K. L. \& Wolfe, D. A. (2002). Child neglect: Developmental issues and outcomes. Child Abuse \& Neglect, 26, 679-695. DOI: 10.1016/s0145-2134(02)00341-1

Hjemdal, O., Friborg, O., Stiles, T., Martinussen, M. \& Rosenvinge, J. (2006). A New Scale for Adolescent Resilience: Grasping the Central Protective Resources Behind Healthy Development. Measurement and Evaluation in Counseling and Development. 39. 84-96. DOI: 10.1080/07481756.2006.11909791.

Hoge, E. A., Austin, E. D. \& Pollack, M. H. (2007), Resilience: Research evidence and conceptual considerations for post-traumatic stress disorder. Depression and Anxiety, 24, 139-152. DOI: 10.1002/da.20175

Holmes, M. R., Yoon, S., Voith, L. A., Kobulsky, J. M. \& Steigerwald, S. (2015). Resilience in physically abused children: protective factors for aggression. Behavioral Sciences, 5(2), 176-189. DOI: 10.3390/bs5020176

Horning, L. E. \& Rouse, K. A. G. (2002). Resilience in preschoolers and toddlers from low-income families. Early Childhood Education Journal, 29(3), 155-159. DOI: 10.1023/A:1014580408103

Howell, K. H. \& Miller-Graff, L. E. (2014). Protective factors associated with resilient functioning in young adulthood after childhood exposure to violence. Child abuse \& neglect, 38(12), 1985-1994. DOI: 10.1016/j.chiabu.2014.10.010

Hyman, B. \& Williams, L. (2001). Resilience Among Women Survivors of Child Sexual Abuse. Affilia, 16(2), 198-219. DOI: $10.1177 / 08861090122094226$

Klein, D. N., Shankman, S. A., Lewinsohn, P. M. \& Seeley, J. R. (2009). Subthreshold depressive disorder in adolescents: predictors of escalation to full-syndrome depressive disorders. Journal of the American Academy of Child \& Adolescent Psychiatry, 48(7), 703-710. DOI: 10.1097/CHI.0b013e3181a56606

Lee, T. Y., Kwong, W. M., Cheung, C. K., Ungar, M. \& Cheung, M. Y. (2010). Children's resilience-related beliefs as a predictor of positive child development in the face of adversities: Implications for interventions to enhance children's quality of life. Social Indicators Research, 95(3), 437 - 453. www.jstor.org/stable/40542303

Liebenberg, L., Theron, L., Sanders, J., Munford, R., Van Rensburg, A., Rothmann, S. \& Ungar, M. (2016). Bolstering resilience through teacher-student interaction: Lessons for school psychologists. School Psychology International, 37(2), 140-154. DOI: 10.1177/0143034315614689

Loh, J. M., Schutte, N, S. \& Thorsteinsson, E, B. (2014). Be happy: The role of resilience between characteristic affect and the symptoms of depression. Journal of Happiness Studies, 15, 1125-1138. DOI: 10.1007/s10902-013-9467-2

Luthar, S. S., Cicchetti, D. \& Becker, B. (2000). The construct of resilience: A critical evaluation and guidelines for future work. Child Development, 71, 543-562. DOI: 10.1111/1467-8624.00164 
Martin, A. J., Bottrell, D., Armstrong, D., Mansour, M., Ungar, M., Liebenberg, L. \& Collie, R. J. (2015). The role of resilience in assisting the educational connectedness of at-risk youth: A study of service users and non-users. International journal of educational research, 74, 1-12. DOI: 10.1016/j.ijer.2015.09.004

Masten, A. S. (2014). Ordinary magic: Resilience in development. New York: The Guilford Press.

Masten, A. S., Hubbard, J. J., Gest, S. D., Tellegen, A., Garmezy, N. \& Ramirez, M. (1999). Competence in the context of adversity: Pathways to resilience and maladaptation from childhood to late adolescence. Development and psychopathology, 11(1), 143-169. DOI: 10.1017/S0954579499001996

McCrory, E., De Brito, S. A. \& Viding, E. (2012). The link between child abuse and psychopathology: a review of neurobiological and genetic research. Journal of the Royal Society of Medicine, 105(4), 151-156. DOI: 10.1258/ jrsm.2011.110222

McLaughlin, K. A. \& Lambert, H. K. (2017). Child trauma exposure and psychopathology: mechanisms of risk and resilience. Current opinion in psychology, 14, 29-34. DOI: 10.1016/j.copsyc.2016.10.004

McLaughlin, K. A., Green, J. G., Gruber, M. J., Sampson, N. A., Zaslavsky, A. M. \& Kessler, R. C. (2012). Childhood adversities and first onset of psychiatric disorders in a national sample of US adolescents. Archives of general psychiatry, 69(11),1151-1160. DOI: 10.1001/archgenpsychiatry.2011.2277

Miljević-Riđički,R., Simões,C \& Kimber, B. (2020) Resilience in school children - A multicultural comparison between three countries - Croatia, Sweden and Portugal, Društvena istraživanja (in press)

Nakai, Y., Inoue, T., Toda, H., Toyomaki, A., Nakato, Y., Nakagawa, S. \& Oba, K. (2014). The influence of childhood abuse, adult stressful life events and temperaments on depressive symptoms in the nonclinical general adult population. Journal of affective disorders, 158, 101-107. DOI: 10.1016/j.jad.2014.02.004

Negele, A., Kaufhold, J., Kallenbach, L. \& Leuzinger-Bohleber, M. (2015). Childhood trauma and its relation to chronic depression in adulthood. Depression research and treatment, 2015. DOI: 10.1155/2015/650804

Norman, R. E., Byambaa, M., De, R., Butchart, A., Scott, J. \& Vos, T. (2012). The longterm health consequences of child physical abuse, emotional abuse, and neglect: A systematic review and meta-analysis. PLoS Med, 9 (11), 1-31. DOI: $10.1371 /$ journal.pmed.1001349

Norton, A. (2017). Exploring the Relationship Between Depression and Resilience in Survivors of Childhood Trauma (Doktorska disertacija, Old Dominion University, Norfolk, Sjedinjene Američke Države). DOI: 10.25777/fbfg$1 \mathrm{w} 65$.

O Afifi, T. \& MacMillan H. L. (2011). Resilience Following Child Maltreatment: A Review of Protective Factors. Canadian Journal of Psychiatry, 56(5), 266-272. DOI: 10.1177/070674371105600505

Petz, B. (ur.) (2005.). Psihologijski rječnik. Jastrebarsko: Naklada Slap

Poole, J. C., Dobson, K. S. \& Pusch, D. (2017). Childhood adversity and adult depression: the protective role of psychological resilience. Child abuse and neglect, 64, 89 - 100. DOI: 10.1016/j.chiabu.2016.12.012

Reuther E.T., Osofsky J.D. (2013). Resilience after Trauma in Early Development. In: Tremblay RE, Boivin M, Peters RDeV, eds. Masten AS, topic ed. Encyclopedia on Early Childhood Development [online]. http://www. child-encyclopedia.com/resilience/according-experts/resilience-after-trauma-early-development. Accessed March $15,2020$.

Schilling, C., Weidner, K., Brähler, E., Glaesmer, H., Häuser, W. \& Pöhlmann, K. (2016). Patterns of childhood abuse and neglect in a representative German population sample. PloS one, 11(7). DOI: 10.1371/journal.pone.0159510

Schoon, I. (2006). Risk and Resilience. Adaptation in Changing Times. Chapter 1. Cambridge University Press. ResearchGate. DOI: 10.1017/CBO9780511490132

Schulz, R. \& Sherwood, P. R. (2008). Physical and mental health effects of family caregiving. Journal of Social Work Education, 44(sup3), 105-113. DOI: 10.1097/01.NAJ.0000336406.45248.4c 
Simeon, D., Yehuda, R., Cunill, R., Knutelska, M., Putnam, F. W. \& Smith, L. M. (2007). Factors associated with resilience in healthy adults. Psychoneuroendocrinology, 32, 1149-1152. DOI: 10.1016/j.psyneuen.2007.08.005

Sousa, C., Herrenkohl, T. I., Moylan, C. A., Tajima, E. A., Klika, J. B., Herrenkohl, R. C. \& Russo, M. J. (2011). Longitudinal study on the effects of child abuse and children's exposure to domestic violence, parent-child attachments, and antisocial behavior in adolescence. Journal of interpersonal violence, 26(1), 111-136. DOI: $10.1177 / 0886260510362883$

Spilman, S. K., Smith, H. L., Schirmer, L. L. \& Tonui, P. M. (2015). Evaluation and treatment of depression in adult trauma patients. Journal of Trauma Nurses, 22, 17-22. DOI: 10.1097/JTN.0000000000000102

Syed, S. A., Cranshaw, M. \& Nemeroff, C. B. (2020). Child abuse and neglect: stress responsivity and resilience. In Stress Resilience (pp. 181-196). Academic Press. DOI: 10.1016/B978-0-12-813983-7.00013-6

Tedeschi, R. G. \& Calhoun, L. G. (2004). A clinical approach to posttraumatic growth. Positive psychology in practice, 405. DOI: 10.1002/9780470939338.ch25

Tempski P., Santos I. S., Mayer F. B., Enns, S. C., Perotta, B., Paro, H. B. M. S., Gannam, S., Peleias, Vera L. G., Baldassin, S., Guimaraes, K. B., Silva, N. R., Navarro da Cruz, E. M. T., Tofoli, L. F., Silveira, P. S. P., Martins, M. A. (2015). Relationship among medical student resilience, educational environment and quality of life. Plos one, 10(6), 1-13. DOI: 10.1371/journal.pone.0131535

Ungar, M. (2008). Resilience across Cultures. The British Journal of Social Work, 38(2), 218-235. DOI: 10.1093/ $\mathrm{bjsw} / \mathrm{bcl} 343$

Ungar, M. (2010). What is resilience across cultures and contexts? Advances to the theory of positive development among individuals and families under stress. Journal of family psychotherapy, 21(1), 1-16. DOI: $10.1080 / 08975351003618494$

Ungar M., Ghazinour, M. \& Richter, J. (2013). Annual research review: What is resilience within the social ecology of human development?. Journal of child psychology and psychiatry, 54(4), 348-366. DOI: 10.1111/jcpp.12025

Ungar, M. \& Liebenberg, L. (2011). Assessing resilience across cultures using mixed methods: Construction of the child and youth resilience measure. Journal of Mixed Methods Research, 5(2), 126-149. DOI: 10.1177/1558689811400607

Van der Kolk B. A., Roth S., Pelcovitz D., Sunday S. \& Spinazzola J. (2005). Disorders of extreme stress: The empirical foundation of a complex adaptation to trauma. Journal of Traumatic Stress, 18(5), 389-399. DOI: 10.1002/jts.20047

Van der Kolk, A. B. (2005). Developmental trauma disorder: toward a rational diagnosis for children with complex trauma histories. Psychiatric Annals, 35(5), 401-408. DOI: 10.13109/prkk.2009.58.8.572

Van Vugt, E., Lanctôt, N., Paquette, G., Collin-Vézina, D. \& Lemieux, A. (2014). Girls in residential care: From child maltreatment to trauma-related symptoms in emerging adulthood. Child Abuse \& Neglect, 38(1), 114-122. DOI: 10.1016/j.chiabu.2013.10.015

Walsh, F. (2016): Family resilience: a developmental systems framework. European Journal of Developmental Psychology, DOI: 10.1080/17405629.2016.1154035

Walsh, W. A., Dawson, J. \& Mattingly, M. J. (2010). How are we measuring resilience following childhood maltreatment? Is the research adequate and consistent? What is the impact on research, practice, and policy?. Trauma, Violence, \& Abuse, 11(1), 27-41. DOI: 10.1177/1524838009358892

Windle, G. (2011). What is resilience? A review and concept analysis. Reviews in Clinical Gereontology, 1-18. DOI: $10.1017 / \mathrm{S} 0959259810000420$

Witt, A., Brown, R. C., Plener, P. L., Brähler, E. \& Fegert, J. M. (2017). Child maltreatment in Germany: prevalence rates in the general population. Child and adolescent psychiatry and mental health, 11(1), 47. DOI: 10.1186/ s13034-017-0185-0

World Health Organization. (2014)? Global status report on violence prevention 2014. World Health Organization. Dostupno na: https://apps.who.int/iris/handle/10665/145086 
Yu, M., Linn, K. A., Shinohara, R. T., Oathes, D. J., Cook, P. A., Duprat, R., Moore, T.M, Oquendo, M.A., Phillips, M.,L., Mcinnis, M., Fava, M., Trivedi, M.H., McGrath, P., Parsey, R., Weissman, M.,M., Sheline, Y.I. (2019). Childhood trauma history is linked to abnormal brain connectivity in major depression. Proceedings of the National Academy of Sciences, 116(17), 8582-8590. DOI: 10.1073/pnas.1900801116

\section{ISPITIVANJE ODNOSA MEHANIZAMA OTPORNOSTI, TRAUME I DEPRESIVNOSTI KOD DJECE}

Sažetak: Definiranje psihološke otpornosti predstavlja izazov za istraživače i stručnjake za mentalno zdravlje. Novija shvaćanja otpornosti definiraju istu kao kapacitet dinamičnog sustava da se uspješno prilagodi na ometajuće čimbenike koji prijete održivosti ili razvoju tog sustava. Ovo istraživanje imalo je za cilj ispitati odnos psihičke traume, depresivnosti i čimbenika otpornosti na kliničkom uzorku djece (N=103). Kako bi se provjerile početne pretpostavke, od mjernih instrumenata korišteni su Ljestvica simptoma traume kod djece (TSCC), Beckovi inventari za mlade-drugo izdanje za djecu i adolescente (BYI-II), Skala procjene otpornosti za djecu i adolescente (CYRM-28) te procjena psihotraumatizacije. Dobiveni rezultati su pokazali kako je pojava zlostavljanja vjerojatnija kod djece čiji skrbnici ne brinu o njihovim fizičkim i psihološkim potrebama. Potvrđeno je kako je nebriga skrbnika o psihološkim potrebama djeteta povezana sa značajnijim negativnim psihološkim ishodima od nebrige skrbnika o fizičkim potrebama. Dodatno, istraživanjem je dobivena veća negativna povezanost otpornosti i depresivnosti kod djece koja su traumatizirana, nego kod netraumatizirane djece. Nadalje, rezultati nisu sasvim u skladu s prijašnjim istraživanjima otpornosti, naime hipoteza da će zlostavljana djeca koja nemaju traumatske reakcije imati značajno više rezultate na upitniku otpornosti od zlostavljanih s izraženim traumatskim reakcijama nije potvrđena te potiče na daljnji nastavak istraživanja.

Ključne riječi: depresija, otpornost, psihička trauma, zlostavljanje 